\section{PRECLINICAL STUDIES OF EFFECTIVENESS AND SAFETY OF IRON OXIDE NANOPARTICLES BASED MRI CONTRAST AGENT FOR TUMOR DIAGNOSTICS}

\author{
Abakumov M.A. 1,2, Prelovskaya A.O.2, Ternovoy S.K.3,4, Demikhov E.I.5, \\ Majouga A.G. $2,6,7$, Chekhonin V.P. ${ }^{1}$
}

1 - Pirogov Russian National Research Medical University.

2 - National Research Technological University "MISiS". Biomedical nanomaterials.

3 - Russian Cardiology Research and Production Complex.

4 - I.M. Sechenov First Moscow State Medical University (Sechenov University).

5 - P.N. Lebedev Physical Institute of the Russian Academy of Sciences.

6 - Moscow State University. Department of Chemistry.

7 - Dmitry Mendeleev University of Chemical Technology of Russia. Moscow, Russia. For citation: Abakumov M.A., Prelouskaya A.O., Ternovoy S.K., Demikhov E.I., Majo A.G., Chekhonin V.P. Preclinical studies of effectiveness and safety of iron oxide nanoparticles based MRI contrast agent for tumor diagnostics. REJR 2018; 8 (4):237-241. DOI:10.21569/2222-7415-2018-8-4-237-241.

Received: $\quad 01.12 .18 \quad$ Accepted: $\quad 12.12 .18$

\section{АОКАИНИЧЕСКИЕ ИССАЕАОВАНИЯ ЭФФЕКТИВНОСТИ И БЕЗОПАСНОСТИ НАНОЧАСТИЦ ОКИСИ ЖЕАЕЗА ААЯ АИАГНОСТИКИ ОПУХОАЕЙ НА ОСНОВАНИИ ААННЫХ МРТ С ВНУТРИВЕННЫМ КОНТРАСТИРОВАНИЕМ}

\section{Абакумов М.А.1,2, Преловская А.О.2, Терновой С.К.3,4, Аемихов Е.И.5, Мажуга А.Г. 2,6,7, Чехонин В.П.'}

агнитные наночастицы оксида железа (MNP) имеют большой потенциал в качестве контрастного вещества для магнитно-резонансной томографии (MPT).

Цель. Оценить эффективность и безопасность контрастного препарата, основанного на магнитных наночастицах оксида железа на модели ортотопической гАиомы С6.

Материалы и методы. Нами проведено обширное доклиническое исследование эффективности такого контрастного вещества. Исследования проводились на модели ортотопической гАиомы С6.

Результаты. В доклинических исследованиях было показано, что покрытые ЧСА магнитные наночастицы оксида железа (MNP-HSA) накапливаются в опухоли и ее крупных сосудах.

Выводы. Полученные данные показывают, что применение наночастиц оксида железа для контрастирования при МРТ дает хорошую визуализацию опухоли и сосудов.

КАючевые слова: магнитно-резонансная томография, магнитные наночастицы, опухомь, рак.

Контактный автор: Абакумов M.A., e-mail: abakumov_ma@rsmu.ru
1 - ФГБОУ ВО «РНИМУ

им. Н.И. Пирогова" Минздрава России. 2 - ФГАОУ ВО «Национальный Исследовательский Технологический Университет "МИСиСм. Ааборатория «Биомедицинские наноматериалы". 3 - ФГБУ «Национальный медицинский исследовательский центр кардиологии" Минздрава России.

4 - ФГАОУ ВО «Первый МГМУ им. И. М. Сеченова" Минздрава России (Сеченовский университет).

5 - ФГБУН «Физический институт им. П.Н. Аебедева" Российской академии наук.

6 - МГУ им. М.В. Аомоносова. Химический факультет.

7 - ФГБОУ ВО «Российский химикотехнологический университет им. Д.И. Менделеева".

г. Москва, Россия. 
Для иитирования: Абакумов М.А., Преловская А.О., Терновой С.К., Демихов Е.И., Мажуга А.Г., Чехонин В.П. Доклиническое исследование эффрективности и безопасности наночастии окиси железа для диагностики опухолей на основании данных с МРТ с внутривенным контрастированием. REJR 2018; 8 (4):237-241. DOI:10.21569/22227415-2018-8-4-237-241.
Статья получена:
01.12.18
Статья принята:
12.12 .18

\section{$\mathrm{I}$}

ntroduction. According to the data, malignant tumors of the brain and central nervous system accounted for 256,000 new cases and 189,000 deaths in $2012(1.8 \%$ of new cancers; $2.3 \%$ of cancer deaths) [1]. Thus, the development of progressive methods for the diagnosis of cancer is required. MRI is one of the most advanced and effective diagnostic methods in clinical practice [2]. Currently, contrast agents based on gadolinium are most often used in clinical practice of MRI, but they can cause complications, such as neurogenic systemic fibrosis and contraindicated in patients with impaired renal function [3]. Magnetic iron oxide nanoparticles in particular $\mathrm{Fe} 3 \mathrm{O} 4$ have a number of advantages: general availability, simplicity and controllability of technology, high level of mutagenic safety and low toxicity for the human body, as well as unique magnetic properties, which provide to reduce the time of longitudinal (T1) and transverse relaxation (T2) [4]. However, having an induced magnetic moment in an external field, unstabilized superparamagnetic iron oxide nanoparticles, when exposed to a strong magnetic field, can directionally move and form aggregates [5]. Minimization of toxicity, agregation and prolongation of circulation of contrast agents based on superparamagnetic iron oxide nanoparticles usually involves postsynthetic modification of the nanoparticles by materials reducing their opsonization [6], so in the coating of nanoparticles was introduced HSA, because human and bovine serum albumins are the main available albumins widely used in the biomedical and pharmaceutical applications [7]. Also, albumin-based nanoparticles have received many attentions because of their biological origin, biodegradability, nontoxicity, non-immunogenicity, water solubility and easy availability [8]. Here we evaluate the efficiency and safety of the contrast agent based on HSA-coated MNP on the model of the $\mathrm{C} 6$ glioma.

\section{Materials and methods.}

Modeling of experimental glioma C6. Glioma C6 line (ATCC No. CCL107), rat glioma induced in vivo by $\mathrm{N}$ nitrosomethylurea, is a monoclonal cell line with fibroblastlike morphology (gift from IstitutoNazionale per la RicercasulCancro). Aliquots of $4 \times 105$ cells were prepared before implantation and stored in $15 \mu \mathrm{L}$ DMEM with antibiotics at $4 \mathrm{oC}$ prior to injection into the brain.
Intracranial tumor was induced in Wistar rats $(190 \pm 10 \mathrm{~g})$ by intracerebral stereotaxic implantation of glioma $\mathrm{C} 6$ cells. The animals were narcotized by intraperitoneal injection of ketamine $(50$ $\mathrm{mg} / \mathrm{kg}$ ) and seduxen $(5 \mathrm{mg} / \mathrm{kg}) ; 2-3$ min later atropine $(0.1 \mathrm{ml})$ was injected subcutaneously. MRI visualization of experimental glioma C6.

Based on the period after the implantation of the tumor and its size, the animals were assigned to one of the groups. For each group of tumors, diagnostics was carried out with magnetic nanoparticles at a dose of 1.5 and $10 \mathrm{mg} / \mathrm{kg}$ by weight of the animal. Contrast agent was injected intravenously into the tail vein of the animal.

MRI visualization of glioblastomas was performed using a 7T MRI scanner (ClinScan, Bruker). To obtain T2-weighted images in the coronary plane, frequency fat suppression was used with the following Turbo Spin Echo (TSE) sequence parameters: $\mathrm{TR} / \mathrm{TE}=4000 / 43 \mathrm{~ms}$, slice thickness $0.5 \mathrm{~mm}$, matrix $288 \times 320, \mathrm{FOV}=40$ $\mathrm{mm}$. To obtain T2-weighted images in the transversal plane: $\mathrm{TR} / \mathrm{TE}=5110 / 57 \mathrm{~ms}$, slice thickness $0.5 \mathrm{~mm}$, matrix $288 \times 320$, FOV $=40 \mathrm{~mm}$.

To obtain T2* weighted images, the SWI mode was used with the following parameters: TE/TR = $19 / 50 \mathrm{~ms}$, slice thickness $0.5 \mathrm{~mm}, \mathrm{FOV}=30 \mathrm{~mm}$, resolution 256/176.

For each animal, a series of images in T2 weighted and SWI modes were obtained before intravenous administration of magnetic nanoparticles, 5 minutes after intravenous administration, 2 and 24 hours after intravenous administration.

\section{Results and Discussion.}

Study of the specific activity.

In all rats subjected to the study, the presence of implanted tumors was verified. The rats were divided into 3 groups according to the size and term of the development of the tumor process on days 5-10 when the tumor is only under development (low severity) and on day 10-15 when the tumor is well established (moderate severity). Comparison MRI scans before and after contrast administration provides information about MNP accumulation and hence, efficiency of visualization of the pathological structures. Results of MRI of rats with low severity level of glioblastoma who received the contrast agent at a dose of $1 \mathrm{mg} / \mathrm{kg}$, $5 \mathrm{mg} / \mathrm{kg}$ and $10 \mathrm{mg} / \mathrm{kg}$ showed that the contrast agent at a dose of 5 and $10 \mathrm{mg} / \mathrm{kg}$ successfully 


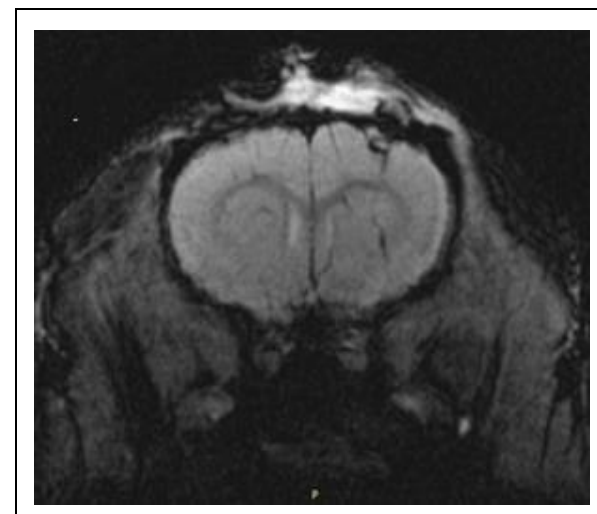

Fig. 1 a (Pис. 1 a)

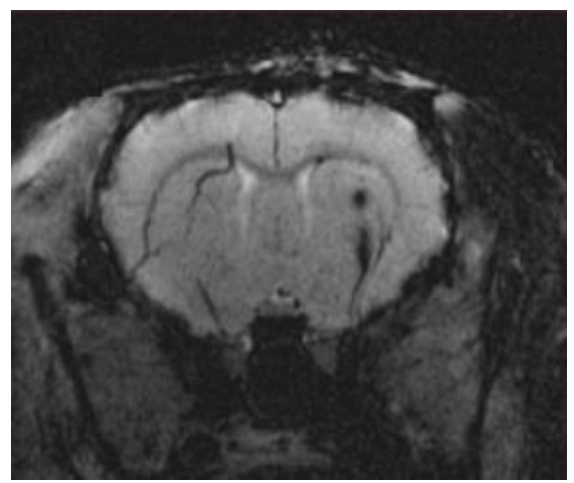

Fig. 1 d (Puc. 1 r)

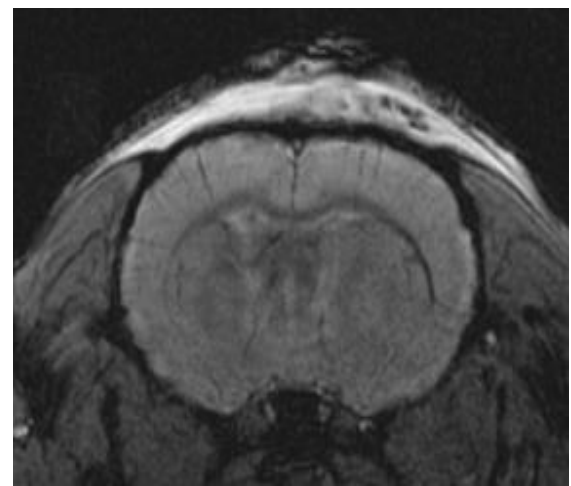

Fig. 1 g (Рис. 1 ж)

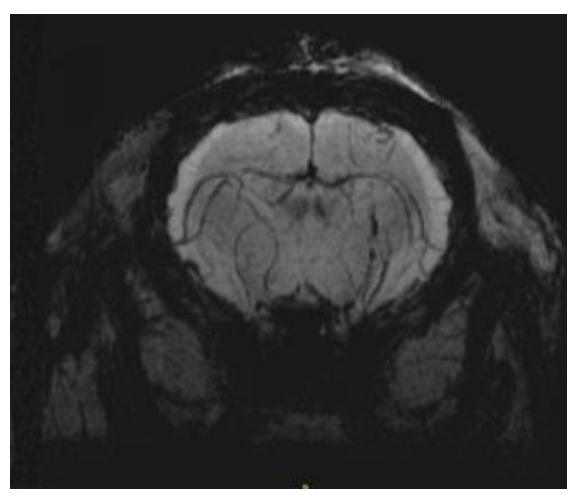

Fig. 1 b (Рис. 1 б)

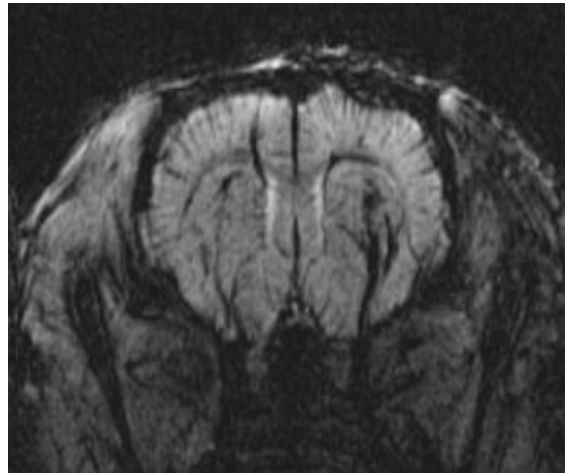

Fig. 1 e (Puc. 1 A)

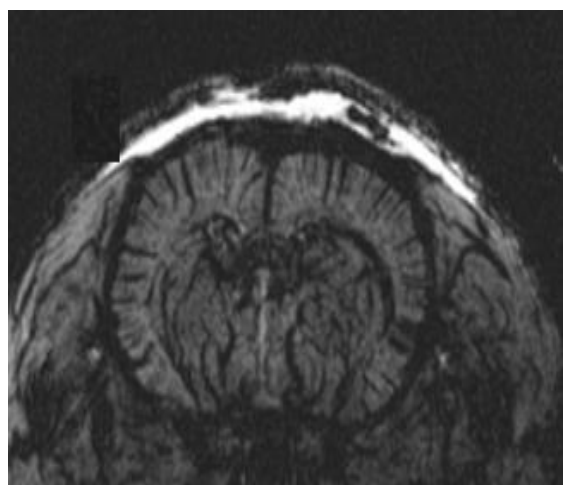

Fig. 1 h (Рис. 1 з)

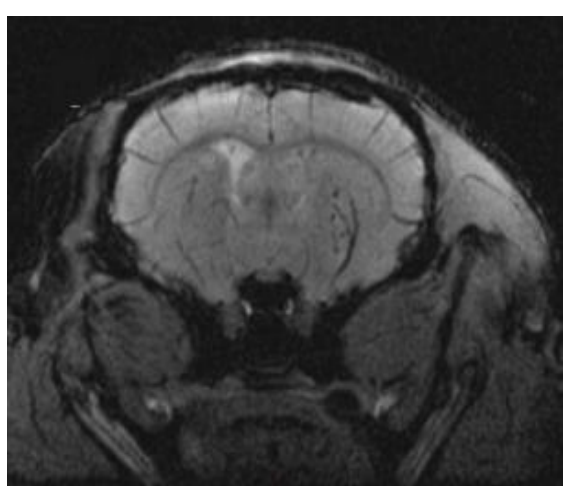

Fig. 1с (Рис. 1 в)

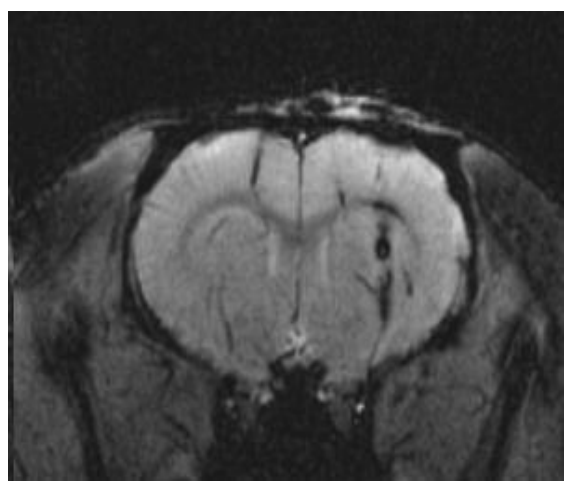

Fig. $1 \mathrm{f}$ (Рис. 1 e)

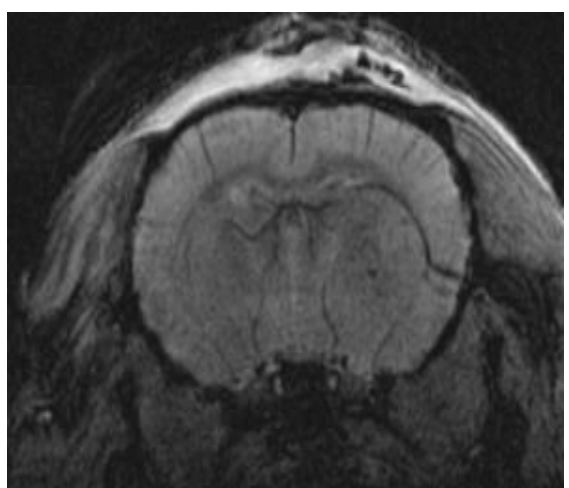

Fig. 1 i (Рис. 1 и)

Fig. 1. MRI.

Representative MRI in SWI sequence of rats bearing experimental C6 glioma 5-10 days after implantation. Left row- before injection, middle row - 5 minutes after injection, right row $-24 \mathrm{~h}$ after injection.

a, b, c- $1 \mathrm{mg} / \mathrm{kg}$ dose,

$\mathrm{d}, \mathrm{e}, \mathrm{f}-5 \mathrm{mg} / \mathrm{kg}$ dose,

$\mathrm{g}, \mathrm{h}, \mathrm{i},-10 \mathrm{mg} / \mathrm{kg}$ dose.

Рис. 1. МРт.

MPT крыс с экспериментальной глиомой С6 в последовательности SWI через 5-10 дней после имплантации. Аевый ряд - до инъекции, средний ряд - через 5 минут после инъекции, правый ряд - через 24 часа после инъекции.

а, б, в - доза $1 \mathrm{mr} / \mathrm{kr}$;

г, д, е - доза $5 \mathrm{мг} / \mathrm{kr}$,

ж, з, и - доза $10 \mathrm{мг/кг.}$ 


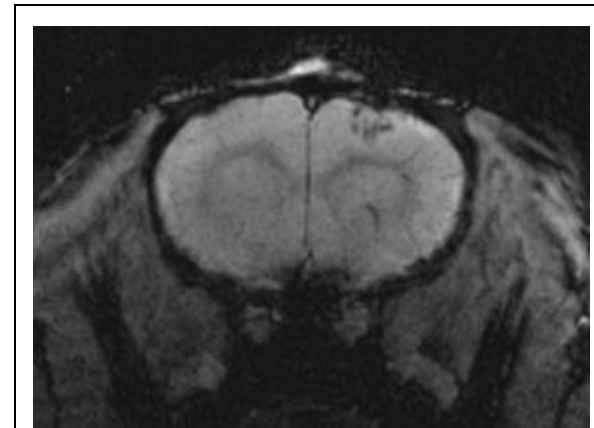

Fig. 2 a (Рис. 2 a)

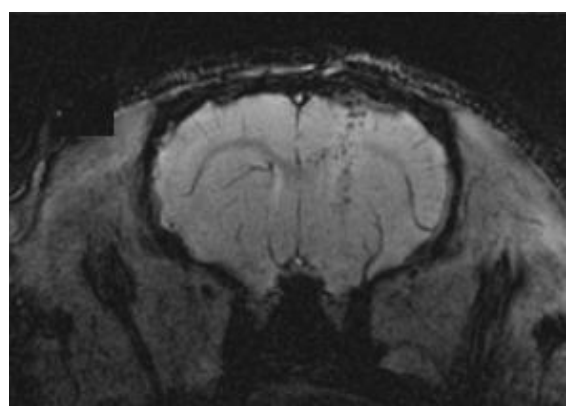

Fig. 2 d (Рис. 2 r)

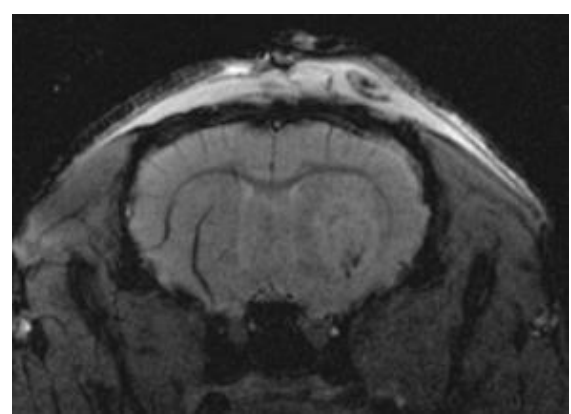

Fig. $2 \mathrm{~g}$ (Рис. 2 ж)

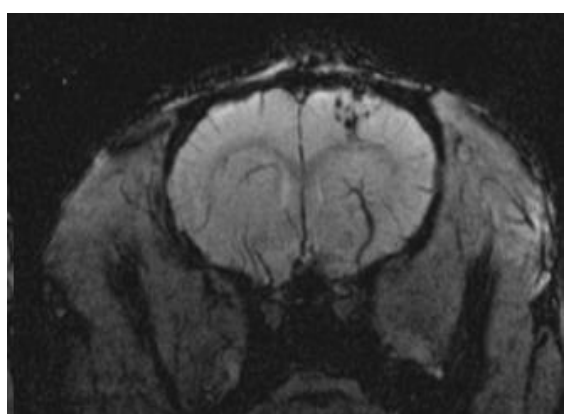

Fig. 2 b (Рис. 2 б)

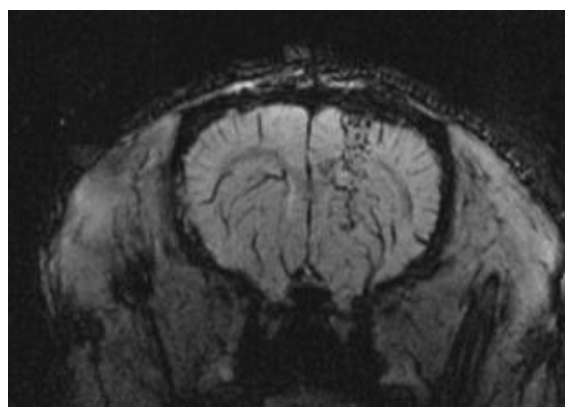

Fig. 2 e (Рис. 2 A)

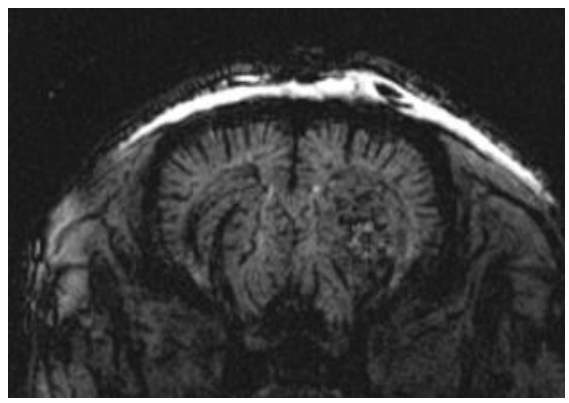

Fig. 2 h (Рис. 2 3)

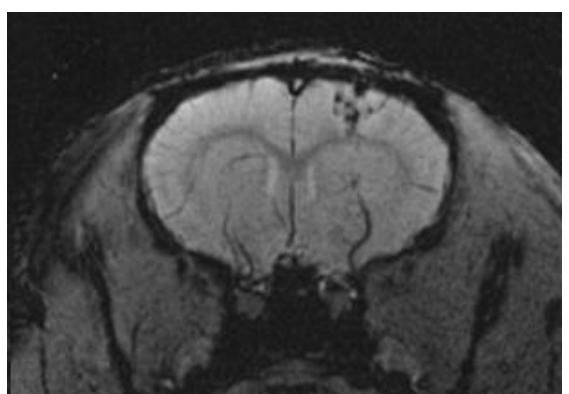

Fig. 2 с (Рис. 2 в)

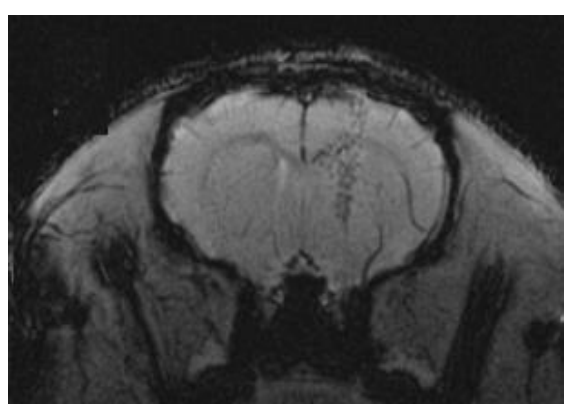

Fig. $2 \mathrm{f}$ (Рис. $2 \mathrm{e}$ )

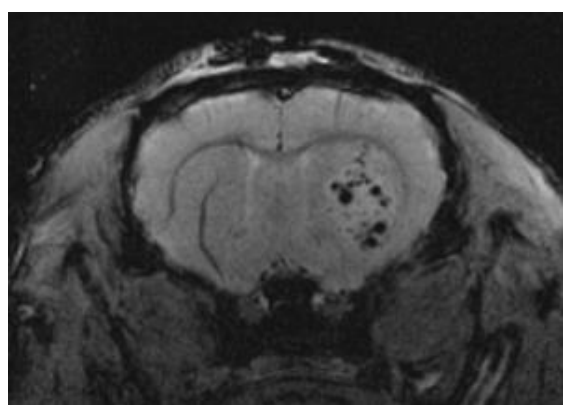

Fig. 2 i (Рис. 2 и)

Fig. 2. MRI.

Representative MRI in SWI sequence of rats bearing experimental C6 glioma 10-15 days after implantation. Left row- before injection, middle row- 5 minutes after injection, right row $-24 \mathrm{~h}$ after injection.

$\mathrm{a}, \mathrm{b}, \mathrm{c}-1 \mathrm{mg} / \mathrm{kg}$ dose,

$\mathrm{d}, \mathrm{e}, \mathrm{f}-5 \mathrm{mg} / \mathrm{kg}$ dose,

$\mathrm{g}, \mathrm{h}, \mathrm{i},-10 \mathrm{mg} / \mathrm{kg}$ dose.

\section{Рис. 2. МРт.}

MPT крыс с экспериментальной глиомой С6 в последовательности SWI через 10-15 дней после имплантации. Аевый ряд - до инъекции, средний ряд - через 5 минут после инъекции, правый ряд - через 24 часа после инъекции.

а, б, в - доза 1 мг/кг;

г, д, е - доза 5 мг/кг,

ж, з, и - доза 10 мг/кг. 


\section{RUSSIAN ELECTRONIC JOURNAL OF RADIOLOGY}

penetrates into the brain vessels and provides them contrasting (fig. $1 \mathrm{E}, \mathrm{H}$ ). But, despite the fact that it is possible to detect the contrast agent in the tumor, in the vessels of the brain, it is impossible to speak of a reliable diagnosis of the tumor process. This may be due to the fact that in the early stages of the tumor process the formation of the tumor body and the vascular bed has not yet taken place, and therefore the contrast agent can't penetrate in tumor. The dose of 1 and $5 \mathrm{mg} / \mathrm{kg}$ is insufficient for confident diagnosis of the tumor (fig. $1 \mathrm{~B}, \mathrm{E}$ ). In the case of the injection of the contrast agent in the dose of $10 \mathrm{mg} / \mathrm{kg}$, there is a massive darkening of areas of the brain associated with a high concentration of magnetic nanoparticles in the bloodstream (fig. $1 \mathrm{H}$ ). In this case the drug longer circulates in the blood, keeping the signal intensity low.

At 10-15 days after tumor implantation, in rats, the development of a tumor focus was observed sufficient for reliable detection. Results of MRI of rats with medium severity levels of glioblastoma who received the contrast agent at a dose of $1 \mathrm{mg} / \mathrm{kg}, 5 \mathrm{mg} / \mathrm{kg}$ and $10 \mathrm{mg} / \mathrm{kg}$ showed that the contrast agent at a dose of $5 \mathrm{mg} / \mathrm{kg}$ accumulates in the vessels of the brain, and especially in the tumor focus (fig. 2 E). Under these conditions, a significant decrease in intensity is observed in the region of the corresponding tumor site), and, in determining the real boundaries of the tumor, the area of the reliably detected focus increases almost two fold than before the injection of the contrast agent. Another interesting effect is the detection of the contrast agent in the brain after 24 hours (fig. $2 \mathrm{~F}$, I). When conducting ex-

\section{References:}

1. Ferlay J., Soerjomataram I., Dikshit R., Eser S., Mathers C., Rebelo M., Parkin D. M., Forman D., Bray F. Int. J. Cancer 2015; 136: E359-E386.

2. Ai H. Adv. Drug Deliv. Rev. 2011; 63: 772-788.

3. Neuwelt E. a, Hamilton B. E., Varallyay C. G., Rooney W. R., Edelman R. D., Jacobs P. M., Watnick S. G. Kidney Int. 2009; 75: 465-474.

4. Jin R., Lin B., Li D., Ai H. Curr. Opin. Pharmacol. 2014; 18C: 18-27.

5. Bronstein L. M., Atkinson J. E., Malyutin A. G., Kidwai F., periments on rats with tumors earlier, none of the animals showed this effect. This phenomenon can be explained by the enhanced permeability and retention effect (EPR) described for a large number of tumors in relation to preparations of the nanoscale range [9].

With the injection of the contrast agent at the dose of $10 \mathrm{mg} / \mathrm{kg}$, a strong signal decrease was observed 5 minutes after injection, and even in healthy vessels a high concentration of the contrast agent was observed, which led to their visual broadening and reducing the diagnostic value of the image (fig. $2 \mathrm{H}$ ). This effect introduces uncertainty in the interpretation of MRI images, what casts doubt on the need to use such a high concentration of the contrast agent in further experiments, provided that at the concentration of 5 $\mathrm{mg} / \mathrm{kg}$ a reliable visualization of the tumor focus is also observed.

\section{Conclusions.}

Overall represented data shows that newly developed contrast agent is highly effective in visualization of tumor boundaries by MRI in T2* weighted sequences. Intensity of the contrast effectiveness shows clear dose-dependent manner in a range of doses from 1 to $10 \mathrm{mg} / \mathrm{kg}$. The most effective for visualization depends lies in the interval form 1 to $10 \mathrm{mg} / \mathrm{kg}$, however smallest doses are not able to provide sufficient effectiveness, whereas highest dose shows very strong drop of signal in both healthy and malignant tissues, thus making hard to differentiate them.

Stein B. D., Morgan D. G., Perry J. M., Karty J. a. Langmuir. 2011; 27: 3044-3050.

6. Laurent S., Forge D., Port M., Roch A., Robic C., Vander Elst L., Muller R. N. Chem. Rev. 2008; 108: 2064-2110.

7. Nosrati H., Sefidi N., Sharafi A., Danafar H., Kheiri Manjili $H$. Bioorg. Chem. 2018; 76: 501-509.

8. Elsadek B., Kratz F. J. Control. Release. 2012; 157: 4-28.

9. Maeda H. Adv. Enzyme Regul. 200., DOI 10.1016/S00652571(00)00013-3. 